\title{
Assessing the regional impact of indonesian biomass burning emissions based on organic molecular tracers and chemical mass balance modeling
}

\author{
G. Engling ${ }^{1}$, J. $\mathrm{He}^{2}$, R. Betha ${ }^{3,4}$, and R. Balasubramanian ${ }^{3,4}$ \\ ${ }^{1}$ Department of Biomedical Engineering and Environmental Sciences, National Tsing Hua University, Hsinchu, Taiwan \\ ${ }^{2}$ Department of Chemical and Environmental Engineering, The University of Nottingham, Ningbo, China \\ ${ }^{3}$ Department of Civil and Environmental Engineering, National University of Singapore, Singapore \\ ${ }^{4}$ Singapore-MIT Alliance for Research and Technology (SMART), Centre for Environmental Sensing and Modeling \\ (CENSAM), Singapore
}

Correspondence to: R. Balasubramanian (ceerbala@nus.edu.sg)

Received: 27 November 2013 - Published in Atmos. Chem. Phys. Discuss.: 28 January 2014

Revised: 17 June 2014 - Accepted: 23 June 2014 - Published: 13 August 2014

\begin{abstract}
Biomass burning activities commonly occur in Southeast Asia (SEA), and are particularly intense in Indonesia during the dry seasons. The effect of biomass smoke emissions on air quality in the city state of Singapore was investigated during a haze episode in October 2006. Substantially increased levels of airborne particulate matter (PM) and associated chemical species were observed during the haze period. Specifically, the enhancement in the concentration of molecular tracers for biomass combustion such as levoglucosan by as much as two orders of magnitude and the diagnostic ratios of individual organic compounds indicated that biomass burning emissions caused a regional smoke haze episode due to their long-range transport by prevailing winds. With the aid of air mass backward trajectories and chemical mass balance modeling, large-scale forest and peat fires in Sumatra and Kalimantan were identified as the sources of the smoke aerosol, exerting a significant impact on air quality in downwind areas, such as Singapore.
\end{abstract}

\section{Introduction}

Air quality in SEA is affected by multiple emission sources, including combustion of fossil fuels for power generation, transportation and industrial processes, biomass burning, and primary as well as secondary emissions from biogenic sources (Balasubramanian et al., 1999, 2003; See et al.,
2006). Biomass burning is a particularly important source of carbonaceous aerosol, resulting from the open burning of agricultural residues, slash-and-burn practices, grassland and forest fires, and residential combustion of biofuels for cooking and heating. Some of the most intense fires, associated with substantial smoke emissions, have occurred many times in Indonesia since the 1990s. Among the different types of biomass burned in Indonesia, peat fires are the key source of smoke haze (Page et al., 2002; See et al., 2007), particularly in El Niño years. Indonesia has the largest area of tropical peatlands in the world, with 27 million hectares scattered across the different provinces (Page et al., 2002). The burning of biomass and organic soil produces large quantities of carbonaceous particles comprising burnt or partially burnt carbon.

Lowland forests and plantations are burnt annually, especially during the dry seasons (March through April and July through October), by farmers and plantation owners as part of land-clearing activities. Such fires can easily get out of control and spread to adjacent forest and peat areas, resulting in large-scale fires. Moreover, the ground in these areas often consists of peat, which is known to sustain smoldering fires for extended periods of time, partly occurring underground, and thus releasing large amounts of smoke. The most intensive fire event recorded in the literature occurred in Indonesia in 1997 (Levine, 1999; Heil and Goldammer, 2001), followed 
by another severe regional haze episode in June 2013 which received considerable international attention.

Investigations of emissions from the combustion of peat are limited to laboratory-scale burning of peat in combustion chambers (e.g., Muraleedharan et al., 2000) and a few field studies (See et al., 2007; Betha et al., 2013). The field studies showed elevated levels of PM number and mass concentrations as well as various chemical species at downwind locations from the biomass burning source regions in Indonesia. Christian et al. (2003) and Iinuma et al. (2007) quantified gaseous as well as particulate components of smoke derived from the combustion of Indonesian peat. It is important to note that combustion conditions are an important factor influencing the physical and chemical properties of the resulting smoke. In the case of peat, due to its chemical nature and high moisture content in typical environments, the combustion process typically proceeds as a smoldering burn, characterized by low combustion efficiency. As a result, peat smoke emissions are high in particulate organic compounds and low in black carbon (BC) content. Despite the environmental significance of wildfires and related chemistry, biomass burning emissions in SEA have received much less attention than other tropical regions such as South America (e.g., Lelieveld et al., 2008; Martin et al., 2010), Africa (e.g., Marticorena et al., 2011; Ferreira et al., 2010), and the Indian subcontinent (e.g., Kulshrestha et al., 2001). More importantly, the quantitative contribution of Indonesian biomass burning to the levels of PM in other countries within SEA in relation to local air pollution sources remains poorly known.

We carried out ambient measurements of total suspended particulate matter (TSP) and its chemical composition in Singapore during a haze episode in 2006. The objectives of this research include: (1) identifying suitable organic molecular tracers for studying the influence of peat and biomass fires on regional air quality, and (2) quantitatively estimating the fractional contribution of these fires to the atmospheric PM loading at a strategically located downwind site based on chemical mass balance modeling.

\section{Experimental procedures}

\subsection{Sampling site and sample collection}

Aerosol samples were collected during two observation periods between September 2006 and January 2007 at the Tropical Marine Science Institute on St. John's Island (SJI), Singapore $\left(1^{\circ} 13^{\prime} 10^{\prime \prime} \mathrm{N} ; 103^{\circ} 50^{\prime} 54^{\prime \prime} \mathrm{E}\right)$. The sampling site was located in an open coastal area in the southern part of Singapore, and was not influenced by local pollution sources from the main island, but potentially by biomass burning emissions from Indonesia. Additional information about the sampling location has been reported previously (Sundarambal et al., 2010). Total suspended particle (TSP) samples were collected for $24 \mathrm{~h}$ three times per week, using a High-
Volume Air Sampler (HVAS, model 3800 AFC, HI-Q Environmental Products Company, USA). The air flow of the HVAS was maintained at $68 \mathrm{~m}^{3} \mathrm{~h}^{-1}$ by a mass flow controller. TSP samples were collected on quartz fiber filters (QM-A, $20.3 \times 25.4 \mathrm{~cm}$, Whatman, UK). All filters used in this study were inspected for defects under bright illumination and were handled with a pair of stainless steel forceps. The TSP filters were folded in half lengthwise after sampling, so that only surfaces with collected particulate matter were in contact, when placed in the filter holder (glassine envelope). The filters were pre-equilibrated in a dry box at constant temperature $\left(22-25^{\circ} \mathrm{C}\right)$ and relative humidity $(30-35 \%)$ for at least $24 \mathrm{~h}$ before weighing. The filters were weighed on a microbalance (model MC5, Sartorius AG, Goettingen, Germany) with a sensitivity of $0.0001 \mathrm{mg}$. The balance was regularly checked with NIST-traceable standard calibrated weights. The pre- and post-sampling weights were used to obtain the particulate mass collected on the filters. All filters were stored in a refrigerator at $4{ }^{\circ} \mathrm{C}$ until analysis. Two field blank filters, one during each observation period, were collected by placing the filters in the sampler for a day without running the sampler and processed together with filter samples.

\subsection{Chemical analyses}

The TSP filter samples were subjected to a series of chemical analyses, including quantification of the common inorganic ions, trace metals, and various organic species. Blank filters were processed according to the same procedures as the sample filters, and the blank values were used to correct the ambient concentrations of the individual chemical species, provided that the blank values were above the method detection limits.

The carbonaceous content of the individual samples was measured as organic carbon (OC) and elemental carbon (EC) by a thermo-optical transmittance (TOT) method, using a Sunset semi-continuous carbon analyzer (Sunset Labs, Model 4, Tigard, OR, USA) in offline mode, based on a modified NIOSH protocol (Birch and Cary, 1996). Polycyclic aromatic hydrocarbons (PAHs) were determined by highperformance liquid chromatography with mass spectrometric detection (HPLC-MS) upon solvent extraction of an additional portion of the filter samples. A Waters Alliance 2695 HPLC system (Waters, Milford, MA, USA), coupled with an API-3000 triple-quadrupole mass spectrometer (Applied Biosystems/MDS SCIEX, Toronto, Canada), equipped with an atmospheric pressure photoionization (APPI) source, was employed for the HPLC-MS analyses. Chromatographic separation of the individual PAHs was achieved with a Waters PAH C18 $(250 \mathrm{~mm} \times 4.6 \mathrm{~mm} \times 5 \mathrm{~mm})$ column (Waters, Milford, MA, USA), using a binary mobile phase system of water and acetonitrile (Z. S. Zhang et al., 2010).

Various carbohydrates, including anhydrosugars, polyols and monosaccharides were separated, identified and 
quantified by high-performance anion exchange chromatography coupled with pulsed amperometric detection (HPAECPAD). A detailed description of the analytical method can be found elsewhere (Engling et al., 2006; Iinuma et al., 2009). Briefly, a portion $\left(2.2 \mathrm{~cm}^{2}\right)$ of each quartz fiber filter was extracted with $2.0 \mathrm{~mL}$ of de-ionized water $(>18.2 \mathrm{M} \Omega$ resistivity) under ultrasonic agitation for $60 \mathrm{~min}$. The aqueous extracts were passed through syringe filters $(0.45 \mu \mathrm{m}$, Pall Corporation, NY, USA) to remove insoluble material. All extract solutions were stored at $4{ }^{\circ} \mathrm{C}$ until sample analysis. The carbohydrate analyses were performed on a Dionex ICS3000 system (Dionex, Sunnyvale, CA, USA), consisting of a DP pump module, DC detector/chromatography compartment and autosampler.

The separation of the individual carbohydrate species was carried out on a Dionex Carbopac MA1 analytical column $(250 \times 4 \mathrm{~mm})$ and guard column with an aqueous sodium hydroxide $(\mathrm{NaOH}, 480 \mathrm{mM})$ eluent at a flow rate of $0.4 \mathrm{~mL} \mathrm{~min}^{-1}$. Method detection limits for the individual analytes ranged from 0.2 to $4.1 \mathrm{ng}$. Quantitative (nearly $100 \%$ ) extraction of the various carbohydrates was shown by analysis of spiked blank filters. None of the carbohydrate species were detected in the blank samples.

Common inorganic ions were determined in the same aqueous extracts as those prepared for HPAEC analysis, using a compact Dionex IC system (Model ICS-2000, Dionex Corp. USA). It consists of an eluent generator (EG with CR-TC), isocratic pump, conductivity detector, anion selfregenerating suppressor (ASRS Ultra II-4 mm), rheodyne six-port injection valve with $25 \mu \mathrm{L}$ injection loop, and AS40 autosampler. An AS-11-HC (4 mm) analytical column in conjunction with an AG-11-HC guard column was used for anion measurement. For cations, the cation-exchange column, CS-12 $(4 \mathrm{~mm})$, was used with $11.0 \mathrm{mM} \mathrm{H}_{2} \mathrm{SO}_{4}$ as the eluent. The peaks corresponding to different analytes in individual standards were identified according to their retention times. The whole IC (Ion Chromatography) operation including calibration and sample analysis was carried out using Chromeleon software.

Both water-soluble and insoluble metals were measured by a Perkin-Elmer Elan 6100 ICP-MS (Perkin-Elmer Inc., USA). The ICP-MS was equipped with a cross flow nebulizer and a quartz torch. The instrument with Pt sampler and skimmer cones was optimized daily and operated as recommended by the manufacturer. The nebulizer gas flow rate was adjusted to keep the $\mathrm{CeO} / \mathrm{Ce}$ and $\mathrm{BaO} / \mathrm{Ba}$ ratios at less than $2 \%$. A Gilson Miniplus 2 peristaltic pump was used to remove the waste from the nebulizer. An eight point calibration $\left(1,2,5,10,20,40,60\right.$, and $\left.100 \mu \mathrm{g} \mathrm{L}^{-1}\right)$ was performed for 13 elements, and the regression coefficients for all $11 \mathrm{el}-$ ements were better than 0.999 . The coefficient of variations for the 13 elements was found to be less than $5 \%(n=10)$ at $5 \mu \mathrm{g} \mathrm{L}{ }^{-1}$ concentration level. Sample handling and preparation were carried out in a laminar flow hood equipped with a HEPA (high-efficiency particulate air) filter to prevent con- tamination. In all experiments, reagent blanks were taken separately. The filter blanks and the final concentrations of metals in PM are reported after reagent blank correction.

\subsection{Source apportionment}

The chemical mass balance air quality receptor model CMB 8.2 (US EPA, 2004) was used to estimate the relative contribution of peat fires and other sources to ambient TSP measured at the sampling site during clear and haze days. Source profiles of inorganic ions and trace elements used in the model were obtained from SPECIATE 4.3 (SPECIATE, 2011). The source profiles for petroleum refinery (Cooper et al., 1987) and diesel emissions (Vega et al., 2004; Chow et al., 2002; Vega et al., 2000) obtained from the USEPA database are applicable to Singapore since the process of refining crude oil, the engineering practices adopted in oil refineries, and the type of diesel used are similar to those in the studies included in the database. In Singapore, most of the powerplants continue to use oil as a fuel of choice, or in tandem with natural gas. Therefore, the source profiles of oil-fired power plants (Henry and Knapp, 1980; Howes et al., 1983) included in the USEPA database were used in the model. Source profiles for Indonesian peat fires were obtained from our previous study (See et al., 2007) while that for ship emissions was obtained from Moldanova et al. (2009) and Popovicheva et al. (2009). The chemical species used in the CMB model were potassium, aluminum, cobalt, chromium, iron, manganese, lead, nickel, cadmium, titanium, vanadium, arsenic, chloride, nitrate, sulfate, ammonium, nitrite, calcium, and sodium.

\subsection{Backward trajectories}

The latest, updated Hybrid Single-Particle Lagrangian Integrated Trajectory (HYSPLIT) model (Version 4.9) (Draxler and Rolph, 2003; Rolph, 2003), developed by the National Oceanic and Atmospheric Administration (NOAA), was used to compute backward trajectories for air samples taken during the haze period (October 2006) and clear days (December 2006-January 2007) in Singapore. Meteorological data were obtained from the National Centers for Environmental Prediction (NCEP) Global Data Assimilation System (GDAS, global, 2006 - present). Kinematic 3-D trajectories were used as they are reported to provide a more accurate description of the history of air masses in comparison with all of the other approaches (isentropic, isobaric) (Stohl, 1998; Stohl and Seibert, 1998). Air mass backward trajectories reaching 4 days $(96 \mathrm{~h}$ ) back were calculated using start times of 08:00 of each sampling period. The calculation heights were fixed at 500, 1000, and $1500 \mathrm{~m}$ above the ground. The atmospheric level, $500 \mathrm{~m}$ a.g.l., is frequently used (Lee et al., 2006; Erel et al., 2007) and ensures that the trajectory ends in the planetary boundary layer (ABL) (Dvorská et al., 2009). 


\section{Results and discussion}

\subsection{Trajectory analysis and temporal variations in TSP concentrations}

The representative air mass backward trajectories for both haze and clear days are presented in Fig. 1 with a haze map for October 2006. The haze period (October 2006) occurred at the end of the southwest monsoon season, within which the climate in Singapore is governed mainly by southwest (SW) or southeast (SE) winds. In this study, the predominant airflow direction was consistent with the general wind pattern and direction from the SE. In October 2006, Singapore was affected by smoke haze transported from uncontrolled biomass and peat burning due to "slash and burn" cultivation in Indonesia, where specifically dense hotspots were observed in Kalimantan and south Sumatra (Fig. 1d and e). During this period, some of the air masses that arrived in Singapore originated from Sumatra (Fig. 1a) while others were advected from Kalimantan with thick haze (Fig. 1b); in addition, on some sampling occasions, the air masses descended (from $1500 \mathrm{~m}$ altitude) or rose (from $500 \mathrm{~m}$ altitude) during the transport, indicating mixing of air masses from different layers on the way to Singapore. During the clear period (December 2006-January 2007), on the other hand, the prevalent wind direction was northeasterly and the major air masses associated with cleaner source regions originated from the South China Sea, characteristic of the northeast monsoon season.

Figure 2 shows the daily average concentrations of total suspended particles (TSP) and Pollution Standard Index (PSI) readings (for south Singapore) which are typically based on $\mathrm{PM}_{10}$ concentrations during haze episodes (Singapore National Environment Agency). It is evident that the daily variation of PSI was well correlated with the variation in TSP concentrations during both haze and clear days.

\subsection{TSP mass balance}

Average concentrations of EC, OC, PAHs, ions, and trace elements are presented in Table 1, as observed during haze (October 2006) and clear (December 2006-January 2007) days on St. John's Island in Singapore. The mean concentration of TSP during the haze period was higher by a factor of 3.5 as compared to clear days. Similarly, the levels of the speciated chemical components of TSP were significantly higher during the haze period than those during clear days. The relative contributions of various chemical species to the total mass concentrations of TSP are shown in Fig. 3. In this figure, "others" refers to the fraction of TSP that was not identifiable (See et al., 2007), where

others $=\mathrm{TSP}-(\mathrm{EC}+\mathrm{OC}+$ inorganic ions + total metals $)$.

During haze days, a noticeably enhanced carbonaceous fraction $(\mathrm{OC}+\mathrm{EC})$ was observed relative to clear days, account- ing for $43 \%$ of TSP mass on average (vs. $25 \%$ on clear days, Fig. 3). It is also worth estimating the amount of organic matter $(\mathrm{OM})$, accounting for heteroatoms in the organic compounds such as oxygen and nitrogen, by applying suitable OM/OC conversion factors. In the case of aerosols measured downwind of biomass burning activities, OM/OC conversion factors of more than 1.4 have been suggested in literature for organic aerosols in urban areas (e.g., White and Roberts, 1977; Turpin and Lim, 2001). When applying a factor of 1.4 to the OC levels detected during the haze period, the content of OM in TSP was found to be extremely high $50 \%$ on average), while it was only around $25 \%$ during clear days. Aside from the substantial increase in the OC or OM fraction, the OC/EC ratio was very high on haze days (15.5 vs. 2.6) compared to clear days, which was higher than the values from most studies reported in the literature (Lee et al., 2006; See et al., 2006, 2007), suggesting the strong influence of biomass burning emissions. It should be noted that high $\mathrm{OC} / \mathrm{EC}$ ratios can also be due to contributions of organic species derived from biogenic sources and secondary organic aerosol (SOA) in particular; however, the source strength of such processes is expected to be fairly constant throughout the year at a tropical location such as Singapore. Therefore, the substantially higher OC/EC ratios observed during the haze period (compared to clear days) confirmed the significant contributions of carbonaceous material derived from biomass burning.

\subsection{Chemical speciation of TSP}

As presented in Table 1, the chemical speciation data include a large number of compounds and elements, such as inorganic ions, trace metals, and various organic species (carbohydrates, PAHs, and carboxylic acids). The substantial increase in the OC mass (by about one order of magnitude) is obviously also reflected in elevated ambient concentrations of individual organic species, specifically in terms of carbohydrates and carboxylic acids. Anhydrosugars, such as levoglucosan, mannosan, and galactosan, are well established molecular tracers for biomass burning emissions, as they are solely derived from the thermal decomposition of cellulose and hemicelluloses (Simoneit et al., 1999). Although recent laboratory studies have revealed that these tracers may be degraded in the presence of oxidants, such as $\mathrm{OH}$ radicals (Hennigan et al., 2010; Hoffmann et al., 2010), the anhydrosugars can be used at least as qualitative indicators of biomass burning influence, but also for quantitative estimates of biomass smoke contributions when transport distances are shorter (Mochida et al., 2010), as was the case with the haze episode in this study. Hennigan et al. (2010) reported that approximately $30-75 \%$ of levoglucosan would react within one day at typical atmospheric $\mathrm{OH}$ levels while Hoffmann et al. (2010) estimated the half-life of levoglucosan to be $12.7-83.2 \mathrm{~h}(0.5-3.5$ days $)$ at $90 \%$ relative humidity. From the backward trajectory analysis, it was observed that 

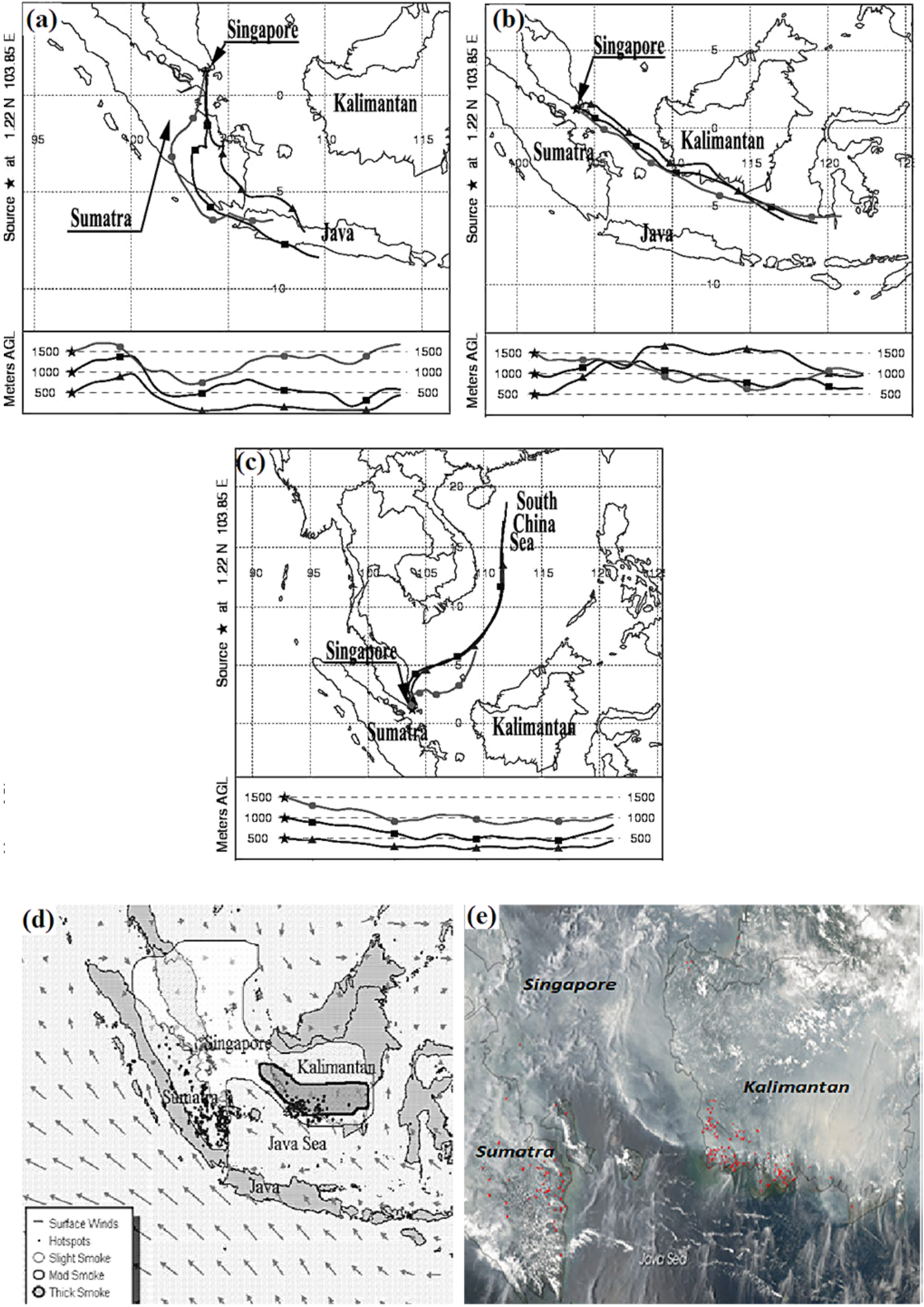

Figure 1. Air mass backward trajectories during haze and clear days in 2006 in Singapore on (a) 7 October 2006; (b) 15 October 2006; (c) 8 January 2007; as well as (d) a haze and fire hotspot map and (e) a satellite image showing smoke due to biomass burning in Sumatra and Kalimantan enveloping the region. 


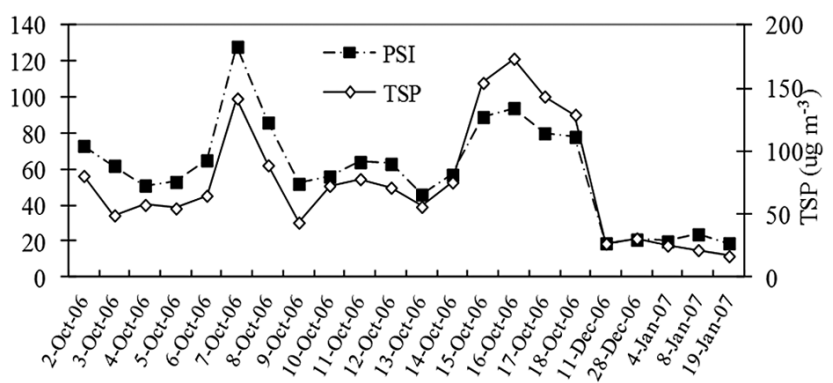

Figure 2. Temporal changes in total suspended particulate matter (TSP) concentrations and Pollutants Standard Index (PSI) during haze (October 2006) and clear (December 2006-January 2007) days in St. John's Island in Singapore.

the air masses from the source regions of biomass burning reached Singapore within 2-3 days, which falls in the range of the half-life of levoglucosan according to Hoffmann et al. (2010). We would like to emphasize here that the ambient concentrations of anhydrosugars were up to two orders of magnitude higher during the haze period relative to the clear days, indicating a massive impact of biomass smoke emissions. In comparison to levoglucosan, the inorganic biomass tracer, potassium, did not show much increase during the haze period. Levoglucosan is a source-specific tracer for biomass burning, as it is generated during thermal breakdown of cellulose and hemicellulose molecules. Potassium, on the other hand, can be derived from various emission sources, including biomass burning, but also from cooking, vegetation, sea salt and soil, especially in the coarse particle fraction. Since in this study we collected TSP, there is likely a substantial contribution of potassium from sources other than biomass burning, namely, sea salt and soil, for which we did not apply a correction. Thus, the increase in potassium concentrations during the haze episode is not expected to be as large as that for levoglucosan.

The inspection of the relative abundance of individual tracers revealed characteristic patterns, which can be used to distinguish periods with smoke influence from the clear days. Specifically, the ratio of the anhydrosugars levoglucosan to mannosan ( $\mathrm{LG} / \mathrm{MN}$ ) can be used for qualitative assessments of contributions from specific biomass species (Engling et al., 2009; Fabbri et al., 2009). For instance, smoke particles derived from softwood combustion are characterized by low $\mathrm{LG} / \mathrm{MN}$ values of 3 to 5 , while hard wood smoke LG/MN ratios range from 15 to 25 and those for rice straw are even higher ( 40$)$. Unlike during the clear days, the LG / MN ratios showed very little variation throughout the haze episode, implying that only one specific biomass type or a steady mix of species was subject to burning. The average LG/MN ratio (10) observed during the haze period is in excellent agreement with chamber burn data from peat combustion (Iinuma et al., 2007) and ambient observations from Malaysia (Si-
Table 1. Mass concentrations of TSP and associated chemical components during haze and clear periods at St. John's Island in Singapore.

\begin{tabular}{|c|c|c|}
\hline & Haze period & Clear days \\
\hline \multicolumn{3}{|c|}{ Concentration (average \pm standard deviation) } \\
\hline \multicolumn{3}{|c|}{$\operatorname{TSP}\left(\mu \mathrm{g} \mathrm{m}^{-3}\right)$} \\
\hline TSP & $94.1 \pm 33.4$ & $24.0 \pm 5.2$ \\
\hline \multicolumn{3}{|c|}{ Carbonaceous components $\left(\mu \mathrm{g} \mathrm{m}^{-3}\right)$} \\
\hline EC & $2.3 \pm 1.5$ & $1.7 \pm 0.50$ \\
\hline $\mathrm{OC}$ & $33.6 \pm 18.9$ & $4.2 \pm 0.53$ \\
\hline $\mathrm{OC} / \mathrm{EC}$ & 15.5 & 2.6 \\
\hline \multicolumn{3}{|c|}{ Polycyclic aromatic hydrocarbons (PAHs) $\left(\mathrm{ng} \mathrm{m}^{-3}\right)$} \\
\hline Benzo & $0.11 \pm 0.05$ & $0.08 \pm 0.06$ \\
\hline Naph & N/A & N/A \\
\hline Acy & $0.11 \pm 0.04$ & $0.04 \pm 0.02$ \\
\hline Ace & $0.05 \pm 0.04$ & $0.02 \pm 0.01$ \\
\hline Flu & $0.06 \pm 0.08$ & $0.02 \pm 0.03$ \\
\hline Phe & $0.62 \pm 0.33$ & $0.08 \pm 0.05$ \\
\hline Ant & $0.02 \pm 0.03$ & N/A \\
\hline Flt & $0.54 \pm 0.18$ & $0.12 \pm 0.08$ \\
\hline Pyr & $0.59 \pm 0.19$ & $0.15 \pm 0.13$ \\
\hline $\mathrm{B}(\mathrm{b}) \mathrm{N}$ & $0.13 \pm 0.01$ & $0.02 \pm 0.01$ \\
\hline Retene & $0.22 \pm 0.06$ & $0.13 \pm 0.05$ \\
\hline $\mathrm{C}(\mathrm{c}, \mathrm{d}) \mathrm{P}$ & $0.58 \pm 0.19$ & $0.20 \pm 0.09$ \\
\hline $\mathrm{B}(\mathrm{a}) \mathrm{A}$ & $0.11 \pm 0.03$ & $0.04 \pm 0.02$ \\
\hline $\mathrm{Chr}$ & $0.05 \pm 0.03$ & $0.04 \pm 0.03$ \\
\hline $\mathrm{B}(\mathrm{e}) \mathrm{P}$ & $0.47 \pm 0.13$ & $0.17 \pm 0.10$ \\
\hline $\mathrm{B}(\mathrm{b}) \mathrm{F}$ & $0.55 \pm 0.13$ & $0.19 \pm 0.12$ \\
\hline $\mathrm{B}(\mathrm{k}) \mathrm{F}$ & $0.32 \pm 0.08$ & $0.12 \pm 0.09$ \\
\hline $\mathrm{B}(\mathrm{a}) \mathrm{P}$ & $0.43 \pm 0.10$ & $0.14 \pm 0.09$ \\
\hline $\mathrm{D}(\mathrm{a}, \mathrm{h}) \mathrm{A}$ & $0.17 \pm 0.09$ & $0.08 \pm 0.02$ \\
\hline $\mathrm{B}(\mathrm{g}, \mathrm{h}, \mathrm{i}) \mathrm{P}$ & $0.80 \pm 0.32$ & $0.17 \pm 0.14$ \\
\hline Ind & $0.63 \pm 0.23$ & $0.19 \pm 0.08$ \\
\hline Cor & $0.34 \pm 0.10$ & $0.09 \pm 0.07$ \\
\hline \multicolumn{3}{|c|}{ Polar organic compounds $\left(\mathrm{ng} \mathrm{m}^{-3}\right)$} \\
\hline Levoglucosan & $1150.9 \pm 917.2$ & $15.3 \pm 5.7$ \\
\hline Mannosan & $115.5 \pm 101.5$ & $4.6 \pm 2.9$ \\
\hline Galactosan & $54.3 \pm 47.7$ & N/A \\
\hline Arabitol & $22.5 \pm 10.6$ & $17.3 \pm 3.5$ \\
\hline Mannitol & $35.4 \pm 5.3$ & $50.9 \pm 5.5$ \\
\hline \multicolumn{3}{|c|}{ Water-soluble ions $\left(\mu \mathrm{g} \mathrm{m}^{-3}\right)$} \\
\hline $\mathrm{F}^{-}$ & $0.18 \pm 0.08$ & $0.01 \pm 0.003$ \\
\hline $\mathrm{Cl}^{-}$ & $1.0 \pm 0.48$ & $0.38 \pm 0.25$ \\
\hline $\mathrm{NO}_{2}^{-}$ & $0.38 \pm 0.21$ & $0.01 \pm 0.003$ \\
\hline $\mathrm{SO}_{4}^{2-}$ & $19.6 \pm 8.5$ & $3.0 \pm 0.74$ \\
\hline $\mathrm{NO}_{3}^{-}$ & $6.4 \pm 2.2$ & $0.76 \pm 0.36$ \\
\hline $\mathrm{PO}_{4}^{3-}$ & $0.46 \pm 0.23$ & $0.09 \pm 0.02$ \\
\hline $\mathrm{Na}^{4}$ & $3.7 \pm 0.64$ & $1.1 \pm 0.40$ \\
\hline $\mathrm{NH}_{4}^{+}$ & $3.0 \pm 2.2$ & $0.07 \pm 0.04$ \\
\hline $\mathrm{K}^{+}$ & $1.6 \pm 0.40$ & $0.42 \pm 0.07$ \\
\hline $\mathrm{Ca}^{2+}$ & $1.7 \pm 1.4$ & $1.1 \pm 0.21$ \\
\hline Acetate & $0.59 \pm 0.32$ & $0.025 \pm 0.015$ \\
\hline Formate & $0.49 \pm 0.27$ & $0.005 \pm 0.009$ \\
\hline Methylsulfonate & $0.15 \pm 0.10$ & N/A \\
\hline
\end{tabular}


Table 1. Continued.

\begin{tabular}{lcc}
\hline & Haze period & Clear days \\
\hline & Concentration (average \pm standard deviation) \\
\hline Succinic & $0.40 \pm 0.25$ & $0.003 \pm 0.003$ \\
Glutorate & $0.51 \pm 0.33$ & $0.005 \pm 0.005$ \\
Malonic acid & $2.3 \pm 1.6$ & $0.008 \pm 0.007$ \\
Oxalate & $5.0 \pm 3.1$ & $0.23 \pm 0.13$ \\
\hline & Total metals (water-soluble metals) & $\left(\mathrm{ng} \mathrm{m}^{-3}\right)$ \\
\hline $\mathrm{Al}$ & $1658.1 \pm 487.7(113.9 \pm 28.3)$ & $1200.0 \pm 697.9(4.9 \pm 1.8)$ \\
$\mathrm{Co}$ & $1.4 \pm 1.1(0.48 \pm 0.42)$ & $0.77 \pm 0.16(0.17 \pm 0.08)$ \\
$\mathrm{Cr}$ & $19.2 \pm 10.4(4.9 \pm 3.0)$ & $8.9 \pm 4.0(1.4 \pm 0.10)$ \\
$\mathrm{Cu}$ & $1129.0 \pm 734.2(13.9 \pm 11.3)$ & $38.7 \pm 19.1(3.14 \pm 1.26)$ \\
$\mathrm{Fe}$ & $1646.9 \pm 1258.5(379.5 \pm 159.4)$ & $1018.8 \pm 389.9(54.0 \pm 10.9)$ \\
$\mathrm{Mn}$ & $27.2 \pm 12.4(17.3 \pm 10.9)$ & $18.4 \pm 3.6(5.7 \pm 2.7)$ \\
$\mathrm{Pb}$ & $27.1 \pm 13.6(14.5 \pm 6.3)$ & $18.2 \pm 3.7(1.3 \pm 0.46)$ \\
$\mathrm{Zn}$ & $68.1 \pm 39.8$ & $96.2 \pm 30.7$ \\
$\mathrm{Cd}$ & $0.99 \pm 0.50$ & $0.66 \pm 0.29$ \\
$\mathrm{Ni}$ & $24.2 \pm 19.2$ & $15.7 \pm 5.2$ \\
$\mathrm{Ti}$ & $626.1 \pm 472.3$ & $534.3 \pm 248.7$ \\
$\mathrm{~V}$ & $71.1 \pm 42.2$ & $47.1 \pm 10.9$ \\
$\mathrm{As}$ & $5.6 \pm 3.1$ & $2.1 \pm 0.86$ \\
\hline
\end{tabular}

moneit et al., 2004), confirming the biomass burning source to be the peatlands in Indonesia.

Two additional carbohydrates, the sugar alcohols arabitol and mannitol, were quantified in the TSP samples in Singapore. These polyols have recently been proposed as bioaerosol indicators and molecular tracers for fungal spores in particular (Bauer et al., 2008a; Elbert et al., 2007). Meanwhile, fungal spore contributions to the aerosol burden have been estimated based on ambient concentrations of these tracers in a few recent studies (Bauer et al., 2008b; Liang et al., 2013; T. Zhang et al., 2010), revealing relatively large fungal spore content specifically in coarse particles in tropical environments (T. Zhang et al., 2010). The average TSP content of these tracers during the haze period in Singapore was not significantly different from that on clear days, indicating no apparent association of fungal spores with biomass smoke particles derived from peat combustion.

Analogous to the carbohydrates, ambient PAH concentrations were substantially higher during the haze period compared to clear days (by factors of 2-5). While PAHs are common combustion products of all carbonaceous materials, including fossil fuels and biomass, diagnostic ratios (DRs) of specific PAH species, although dependent on aerosol age, can be used to constrain the predominant influence of emissions from certain types of combustion. For instance, Ind/(Ind $+\mathrm{B}(\mathrm{g}, \mathrm{h}, \mathrm{i}) \mathrm{P})>0.5$ indicates sources of solid fuel combustion (such as coal, wood, grass, etc.) and ratios $<0.2$ indicate petroleum origin, while the ratios between $0.2-$ 0.5 indicate liquid fossil fuel combustion (vehicles and crude oil) (Yunker et al., 2002). Similarly, Flt/(FIt + Pyr) $<0.4$ is attributable to unburned petroleum, a ratio $\geq 0.5$ indicates coal, grass and wood combustion origins, while ratios between $0.4-0.5$ indicate liquid fossil fuel combustion (Yunker et al., 2002). In this study the ratios of Ind/(Ind $+\mathrm{B}(\mathrm{g}, \mathrm{h}, \mathrm{i}) \mathrm{P})$ and Flt/(FIt + Pyr $)$ were found to be in the range of $0.51-$ 0.57 and $0.47-0.55$, respectively, during haze days, while they ranged from $0.41-0.47$ and $0.40-0.45$ during clear days, suggesting that the dominant contributor is biomass burning during the haze period and is local sources, such as ships and diesel engines, during clear days.

All of the common inorganic ions were present at higher levels in TSP during the haze period, with enhancements of up to one order of magnitude in some cases (e.g., ammonium). Aside from ammonium, potassium and nitrate also showed significantly higher ambient concentrations in the haze vs. clear periods, confirming the strong influence of biomass burning activities on the local aerosol burden.

During the haze period, dicarboxylic acids (succinate, malonate, glutarate, and oxalate) were much more abundant than monocarboxylic acids (acetate and formate); oxalate was the predominant dicarboxylic acid. Analogous to other organic species, the mass concentrations of organic acids observed during the haze period were much higher than those obtained during the clear days, suggesting that biomass burning is an important source of organic acids. These acids could have been directly emitted from the biomass burning source (e.g., peat fires) and/or formed in the atmosphere as a result of chemical conversions in the biomass burning smoke plume (See et al., 2007). In case of the haze episode observed in this study, a substantial portion of the dicarboxylic acids 
(a)

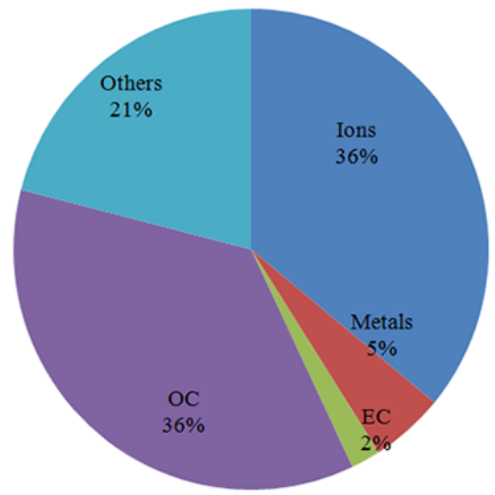

(b)

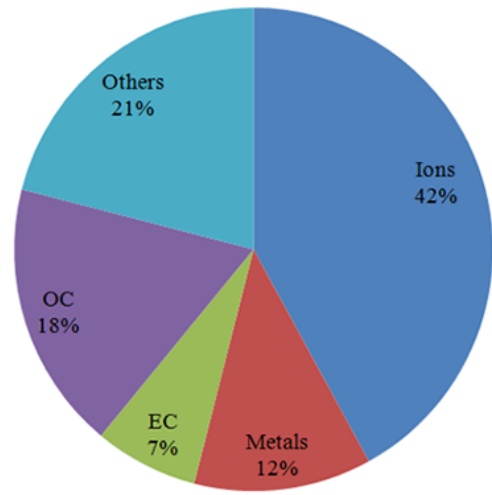

Figure 3. Mass balance of TSP sampled during haze (a) and clear days (b) at St. John's Island in Singapore.

was likely derived from atmospheric oxidation, namely, aging processes, during transport of the smoke particles to the sampling site in light of the favorable conditions. A substantial increase in water-soluble organics in smoke aerosols, including organic acids, has also been reported from previous studies in SEA and elsewhere (Agarwal et al., 2010; Graham et al., 2002; Gao et al., 2003; Kundu et al., 2010).

Both total and water-soluble metal concentrations were determined in the TSP samples collected during the haze period and clear days in Singapore. The concentrations of most trace metals were clearly enhanced during the haze period in relation to those on clear days. The most abundant trace metals found in haze samples were $\mathrm{Cu}, \mathrm{Al}, \mathrm{Fe}$, and $\mathrm{Ti}$. The substantial increase in the metallic species concentrations of peat/vegetation, as the metals $\mathrm{Al}, \mathrm{Fe}$, and $\mathrm{Ti}$ are also the top three most abundant metals in Earth's crust. (Lide, 2005). As for copper, total $\mathrm{Cu}$ concentrations during the haze period were 30 times higher on average compared to those on clear days. This phenomenon may be due to the strong fixation ability of water-soluble copper compounds by rich humic and fulvic acids in the peat soils (Mutert et al., 1999); upon combustion, this part of copper can be subsequently discharged into the ambient air. The low solubility of this metal could be due to the chemical form in which it exists such as metal oxides produced during high-temperature combustion. These oxides are in general less soluble as compared to metal nitrates/sulfates. There is a copper mine (Beutong mine, one of the largest copper mine in Indonesia) in the Sumatra region where peat fires occurred during the haze episode which could be one of the additional sources of copper apart from peat emissions. However, whether or not the soil in this local area contains high concentrations of copper needs to be further investigated. In addition, the water-soluble fraction of most metals was larger by a factor of 5 or more during haze vs. clear periods. This could be due to strong (more effective) attachment of organic matter to the metals in the newly formed particles emitted during biomass burning processes. As mentioned earlier, organic acids were much more enriched in the haze aerosols than those on clear days. The presence of organic ligands can result in the formation of soluble heavy metal complexes (See et al., 2007; Gaberell et al., 2003). Some of the metals such as Al have shown a significantly higher proportion of the water soluble fraction ( $\sim 30$ times) during the haze compared to clear days. In general, the water solubility of a metal depends on the chemical form in which it is present. The higher water-soluble fraction of $\mathrm{Al}$ observed during the haze might be due to the presence of more soluble $\mathrm{Al}$ chemical species in haze aerosols. However, additional investigation is necessary to examine the chemical fractionation of particulate-bound metals using a sequential extraction procedure. This investigation will account for (1) soluble and exchangeable metals; (2) carbonates, oxides, and reducible metals; (3) metals bound to organic matter, oxidizable and sulfidic metals; and (4) residual metals, while the current study quantified only the soluble and exchangeable metals. The outcome of the investigation will be published elsewhere.

\subsection{Source apportionment}

Contributions of particulate matter from different emission sources can be assessed by a variety of methods. As a large number of chemical species was quantified in the TSP samples as part of this study, the chemical mass balance (CMB) modeling approach was applied here, providing reliable estimates of the individual sources (Watson et al., 2002). Figure 4 shows the relative source contributions to ambient TSP at the sampling site during haze and clear days. The CMB performance-measured indices are all within the target ranges recommended by the US EPA $\left(r^{2}: 0.8-1 ; \chi^{2}: 0-4 ; \%\right.$ mass: $80-120 \%$; degrees of freedom $>5 ; t$ stat $>2$ for all the contribution sources). The major pollution sources that affected the air quality at the sampling site were identified to be peat fires, diesel exhaust, petroleum refineries, ships, and power plants during the sampling period. From Fig. 4, it can be seen that diesel exhaust was the dominating source on a typical clear day. The sampling site is remotely located, away from the main land of Singapore, so that the power supply for 

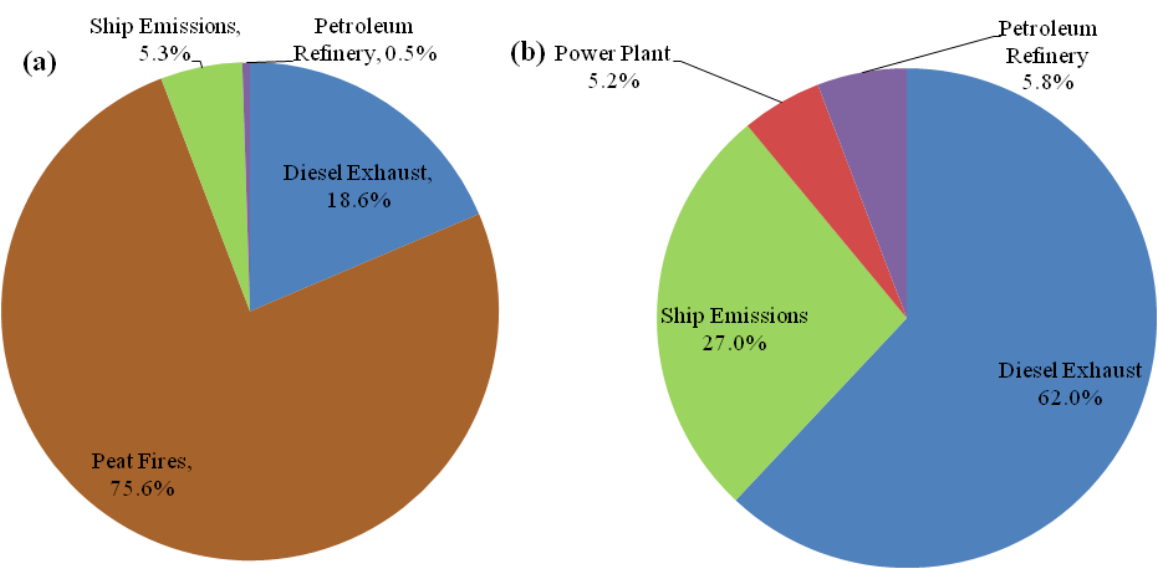

\begin{tabular}{lll}
\hline$\left(\mu \mathrm{g} . \mathrm{m}^{-3}\right)$ & (a) Haze & (b) Clear days \\
\hline Ship Emissions & $4.46 \pm 1.77$ & $6.48 \pm 1.4$ \\
Petroleum Refinery & $0.42 \pm 0.17$ & $0.59 \pm 0.3$ \\
Power Plant & - & $0.55 \pm 0.27$ \\
Diesel Exhaust & $15.64 \pm 6.21$ & $14.88 \pm 3.22$ \\
Peat Fires & $63.58 \pm 25.25$ & - \\
\hline
\end{tabular}

Figure 4. Source contributions to TSP during haze (a) and clear days (b) at St. John's Island in Singapore.

the entire island is provided by diesel generators which could be the reason for the diesel exhaust being a major contributor to PM $(\sim 62 \%)$ at the sampling site. Ships that pass by the island to reach the Singapore port also contributed to TSP $(27 \%)$, followed by a nearby petroleum refinery $(\sim 6 \%)$ and power plants $(\sim 5 \%)$. During the haze episode, peat fires in Indonesia were the predominant source $(\sim 76 \%)$ of TSP followed by diesel exhaust (19\%), and ship emissions $(\sim 5 \%)$.

\section{Conclusions}

In this study, the impact of a major smoke haze episode, caused by biomass burning and peat fires in Indonesia, on regional air quality in Singapore was investigated during autumn 2006. It was observed that the TSP concentration increased by a factor of 3.5 with the major contribution from the carbonaceous fraction $(\sim 43 \%)$ during the haze episode when compared to clear days (carbonaceous fraction $\sim 25 \%$ ). Very high OC/EC ratios (15.5), concentrations of organic acids, PAHs, and trace metals, especially $\mathrm{Cu}, \mathrm{Al}, \mathrm{Fe}$ and $\mathrm{Ti}$, in TSP observed during the haze period reveal the impact of Indonesian biomass burning activities on regional air quality in SEA. Enhancement in the concentrations of organic molecular tracers of biomass burning, as well as a diagnostic ratio of LG/ MN of 10 observed during the haze period is in excellent agreement with the laboratory data from controlled peat combustion, confirming the biomass burning source to be the peatlands in Indonesia. Similarly, the diagnostic ratios of PAH species indicate that the TSP during the haze period was predominantly influenced by biomass burning while it was mainly influenced by local fossil fuel combustion and diesel engine emissions during clear days. Source apportionment using the CMB model indicated that on clear days, TSP at the sampling location was mainly derived from exhaust $(\sim 62 \%)$ from local diesel generators which is the only source of power on the Island, followed by ships $(27 \%)$, a petroleum refinery $(\sim 6 \%)$, and power plants $(\sim 5 \%)$. On the other hand, during the haze period nearly $76 \%$ of the TSP was derived from peat fires in Indonesia, reducing the source contribution of diesel exhaust and ship emissions at the sampling site to 19 and $5 \%$, respectively.

Acknowledgements. The authors R. Betha and R. Balasubramanian acknowledge the financial support from the National University of Singapore and from the National Research Foundation Singapore through the Singapore-MIT Alliance for Research and Technology's CENSAM research program and National University of Singapore (NUS) for carrying out this study.

Edited by: J. Allan

\section{References}

Agarwal, S., Aggarwal, S. G., Okuzawa, K., and Kawamura, K.: Size distributions of dicarboxylic acids, ketoacids, $\alpha$ dicarbonyls, sugars, WSOC, OC, EC and inorganic ions in atmospheric particles over Northern Japan: implication for long-range transport of Siberian biomass burning and East Asian polluted aerosols, Atmos. Chem. Phys., 10, 5839-5858, doi:10.5194/acp10-5839-2010, 2010. 
Balasubramanian, R., Victor, T., and Begum, R.: Impact of biomass burning on rainwater acidity and composition in Singapore, J. Geophys. Res., 104, 881-890, 1999.

Balasubramanian, R., Qian. W. B., Decesari. S., Facchini, M. C., and Fuzzi, S.: Comprehensive characterization of $\mathrm{PM}_{2.5}$ aerosols in Singapore, J. Geophys. Res., 108, 4523, doi:10.1029/2002JD002517, 2003.

Bauer, H., Claeys, M., Vermeylen, R., Schueller, E., Weinke, G., Berger, A., and Puxbaum, H.: Arabitol and mannitol as tracers for the quantification of airborne fungal spores, Atmos. Environ., 4, 588-593, 2008a.

Bauer, H., Schueller, E., Weinke, G., Berger, A., Hitzenberger, R., Marr, I. L., and Puxbaumm H.: Significant contributions of fungal spores to the organic carbon and to the aerosol mass balance of the urban atmospheric aerosol, Atmos. Environ., 42, 55425549, 2008b.

Betha, R., Pradani, M., Lestari, P., Joshi, U. M., Reid, J. S., and Balasubramanian, R.: Chemical speciation of trace metals emitted from Indonesian peat fires for health risk assessment, Atmos. Res., 122, 571-578, 2013.

Birch, M. E. and Cary, R. A.: Elemental carbon-based method for monitoring occupational exposures to particulate diesel exhaust, Aerosol Sci. Tech., 25, 221-241, 1996.

Chow, J. C., Watson, J. G., Edgerton, S. A., and Vega, E.: Chemical composition of $\mathrm{PM}_{10}$ and $\mathrm{PM}_{2.5}$ in Mexico City during winter 1997, Sci. Total Environ., 287, 177-201, 2002.

Christian, T. J., Kleiss, B., Yokelson, R. J., Holzinger, R., Crutzen, P. J., Hao, W. M., Saharjo, B. H., and Ward, D. E.: Comprehensive laboratory measurements of biomass-burning emissions: 1 . Emissions from Indonesian, African, and other fuels, J. Geophys. Res., 108, 4719, doi:10.1029/2003JD003704, 2003.

Cooper, J. A., Redline, D. C., Sherman, J. R., Valdovinos, L. M., Pollard, W. L., Scavone, L. C., and Badgett-West, C.: PM 10 Source composition Library for the South Coast Air Basin. Volume I and II. Prepared for the South Coast Air Quality Management District, El Monte, CA, 15 July 1987.

Draxler, R. R. and Rolph, G. D.: HYSPLIT (Hybrid SingleParticle Lagrangian Integrated Trajectory) Model access via NOAA ARL READY. NOAA Air Resources Laboratory, available at: http://www.arl.noaa.gov/ready/hysplit4.html (last access: 20 June 2013), Silver Springs, M.D., USA, 2003.

Dvorská, A., Lammel, G., and Holoubek, I.: Recent trends of persistent organic pollutants in air in central Europe-Air monitoring in combination with air mass trajectory statistics as a tool to study the effectivity of regional chemical policy, Atmos. Environ., 43, 1280-1287, 2009.

Elbert, W., Taylor, P. E., Andreae, M. O., and Pöschl, U.: Contribution of fungi to primary biogenic aerosols in the atmosphere: wet and dry discharged spores, carbohydrates, and inorganic ions, Atmos. Chem. Phys., 7, 4569-4588, doi:10.5194/acp-7-4569-2007, 2007.

Engling, G., Carrico, C. M., Kreidenweis, S. M., Collett, J. L., Day, D. E., Malm, W. C., Lincoln, E., Hao, W. M., Iinuma, Y., and Hermann, H.: Determination of levoglucosan in biomass combustion aerosol by high-performance anion-exchange chromatography with pulsed amperometric detection, 40, S299S311, 2006.

Engling, G., Lee, J. J., Tsai, Y.-W., Lung, S.-C. C., Chou, C. C.K., and Chan, C. Y.: Size-Resolved Anhydrosugar Composition in Smoke Aerosol from Controlled Field Burning of Rice Straw, Aerosol. Sci. Tech., 43, 662-672, 2009.

Erel, Y., Kalderon-Asael, B., Dayan, U., and Sandler, A.: European atmospheric pollution imported by cooler air masses to the Eastern Mediterranean during the summer, Environ. Sci. Technol., 41, 5198-6003, 2007.

Fabbri, D., Torri, C., Simonei, B. R. T., Marynowski, L., Rushdi, A. I., and Fabianska, M. J.: Levoglucosan and other cellulose and lignin markers in emissions from burning of Miocene lignites, Atmos. Environ., 43, 2286-2295, 2009.

Ferreira, J., Reeves, C. E., Murphy, J. G., Garcia-Carreras, L., Parker, D. J., and Oram, D. E.: Isoprene emissions modelling for West Africa: MEGAN model evaluation and sensitivity analysis, Atmos. Chem. Phys., 10, 8453-8467, doi:10.5194/acp-10-84532010, 2010.

Gaberell, M., Chin, Y. P., Hug, S. J., and Sulzberger, B.: Role of dissolved organic matter composition on the photoreduction of $\mathrm{Cr}(\mathrm{VI})$ to $\mathrm{Cr}(\mathrm{III})$ in the presence of iron, Environ. Sci. Technol., 37, 4403-4409, 2003.

Gao, S., Hegg, D. A., Hobbs, P. V., Kirchstetter, T. W., Magi, B. I., and Sadilek, M.: Water-soluble organic compounds in aerosols associated with savanna fires in southern Africa: identification, evolution, and distribution, J. Geophys. Res., 108, 8491-8506, 2003.

Graham, B., Mayol-Bracero, O. L., Guyon, P., Roberts, G. C., Decesari, S., Facchini, M. C., Artaxo, P., Maenhaut, W., Koil, P., and Andreae, M. O.: Water-soluble organic compounds in biomass burning aerosols over Amazonia. 1. Characterization by NMR and GC-MS, J. Geophys. Res., 107, 8047-8062, 2002.

Heil, A. and Goldammer, J. G.: Smoke-haze pollution: a review of the 1997 episode in Southeast Asia, Reg. Environ. Change, 2, 24-37, 2001.

Hennigan, C. J., Sullivan, A. P., Collett, J. L., and Robinson, A. L.: Levoglucosan stability in biomass burning particles exposed to hydroxyl radicals, Geophys. Res. Lett., 37, L09806, doi:10.1029/2010GL043088, 2010.

Henry, W. M. and Knapp, K. T.: Compound Forms of Fossil Fuel Fly Ash Emissions, Environ Sci. Technol., 14, 450-456, 1980.

Hoffmann, D., Tilgner, A., Iinuma, Y., and Herrmann, H.: Atmospheric Stability of Levoglucosan: A Detailed Laboratory and Modeling Study, Environ. Sci. Technol., 44, 694-699, 2010.

Howes, J. E., Cooper, J. A., and Houck, J. E.: Sampling and Analysis to Determine Source Signatures in the Philadelphia Area. Draft Final Report to US Environmental Protection Agency, ESRL, Research Triangle Park, NC, NEA, Inc. 1983.

Iinuma, Y., Bruggemann, E., Gnauk, T., Mueller, K., Andreae, M. O., Helas, G., Parmar, R., and Herrmann, H.: Source characterization of biomass burning particles: The combustion of selected European conifers, African hardwood, savanna grass, and German and Indonesian peat, J. Geophy. Res., 112, D08209, doi:10.1029/2006JD007120, 2007.

Iinuma, Y., Engling, G., Puxbaum, H., and Hermann, H.: A highly resolved anion-exchange chromatographic method for determination of saccharidic tracers for biomass combustion and primary bio-particles in atmospheric aerosol, Atmos. Environ., 43, 13671371, 2009.

Kulshrestha, U., Jain, M., Sekar, R., Vairamani, M., Sarkar, A., and Parashar, D.: Chemical characteristics and source apportionment 
of aerosols over Indian Ocean during INDOEX-1999, Curr. Sci., 80, 180-185, 2001.

Kundu, S., Kawamura, K., Andreae, T. W., Hoffer, A., and Andreae, M. O.: Molecular distributions of dicarboxylic acids, ketocarboxylic acids and $\alpha$-dicarbonyls in biomass burning aerosols: implications for photochemical production and degradation in smoke layers, Atmos. Chem. Phys., 10, 2209-2225, doi:10.5194/acp-10-2209-2010, 2010.

Lee, K. H., Kim, Y. J., and Kim, J. J.: Characteristics of aerosol observed during two severe haze events over Korea in June and October 2004, Atmos. Environ., 40, 5146-5155, 2006.

Lelieveld, J., Butler, T. M., Crowley, J. N., Dillon, T. J., Fischer, H., Ganzeveld, L., Harder, H., Lawrence, M. G., Martinez, M., Taraborelli, D., and Williams, J.: Atmospheric oxidation capacity sustained by a tropical forest, Nature, 452, 737-740, 2008.

Levine, J. S.: The 1997 fires in Kalimantan and Sumatra, Indonesia: Gaseous and particulate emissions, Geophy. Res. Lett., 26, 815818, 1999

Liang, L., Engling, G., He, K., Du, Z., Cheng, Y., and Duan, F.: Evaluation of fungal spore characteristics in Beijing, China, based on molecular tracer measurements, Environ. Res. Lett., 8, 014005, doi:10.1088/1748-9326/8/1/014005, 2013.

Lide, D. R.: Geophysics, Astronomy, and Acoustics, Abundance of Elements in the Earth's crust and in the Sea, in: CRC Handbook of Chemistry and physics, CRC Press:Boca Raton, FL, 14-14, 2005.

Maldanova, J., Fridell, E., Popovicheca, O., Demirdjian, B., Tishkova, V., Faccinetto, A., and Focsa, C.: Characterization of particulate matter and gaseous emissions from a large ship diesel engine, Atmos. Envrion., 43, 2632-2641, 2009.

Marticorena, B., Haywood, J., Coe, H., Formenti, P., Liousse, C., Mallet, M., and Pelon, J.: Tropospheric aerosols over West Africa: highlights from the AMMA international program, Atmos. Sci. Lett., 12, 19-23, 2011.

Martin, S. T., Andreae, M. O., Althausen, D., Artaxo, P., Baars, H., Borrmann, S., Chen, Q., Farmer, D. K., Guenther, A., Gunthe, S. S., Jimenez, J. L., Karl, T., Longo, K., Manzi, A., Müller, T., Pauliquevis, T., Petters, M. D., Prenni, A. J., Pöschl, U., Rizzo, L. V., Schneider, J., Smith, J. N., Swietlicki, E., Tota, J., Wang, J., Wiedensohler, A., and Zorn, S. R.: An overview of the Amazonian Aerosol Characterization Experiment 2008 (AMAZE08), Atmos. Chem. Phys., 10, 11415-11438, doi:10.5194/acp10-11415-2010, 2010.

Mochida, M., Kawamura, K., Fu, P. Q., and Takemura, T.: Seasonal variation of levoglucosan in aerosols over the western North Pacific and its assessment as a biomass-burning tracer, Atmos. Environ., 44, 3511-3518, 2010.

Muraleedharan, T. R., Radojevic, M., Waugh, A., and Caruana, A.: Emissions from the combustion of peat: An experimental study, Atmos. Environ., 34, 2733-2738, 2000.

Mutert, E., Fairhurst, T. H., and von Hexküll, H. R.: Agronomic management of oil palms on deep peat, Better Crops International, 13, 22-27, 1999.

Page, S. E., Siegert, F., Rieley, J. O., Boehm, H.-D. V., Jaya, A., and Limin, S.: The amount of carbon released from peat and forest fires in Indonesia during 1997, Nature, 420, 61-65, 2002.

Popovicheca, O., Kireeva, E., Shonija, N., Zubareva, N., Persiantseva, N., Tishkova, V., Demirdjian, B., Moldanova, J., and Mogilnikov, V.: Ship particulate pollutants: Characterization in terms of environmental implication, J. Environ. Monitor., 11, 2077-2086, 2009.

Rolph, G. D.: Real-time Environmental Applications and Display sYstem (READY) Website, available at: http://www.arl.noaa. gov/ready/hysplit4.html (last access: 20 June 2013), NOAA Air Resources Laboratory, Silver Spring, MD, USA, 2003.

See, S. W., Balasubramanian, R., and Wang, W.: A study of the physical, chemical, and optical properties of ambient aerosol particles in Southeast Asia during hazy and nonhazy days, J. Geophys. Res., 111, D10S08, doi:10.1029/2005JD006180, 2006.

See, S. W., Balasubramanian, R., Rianawati, E., Karthikeyan, S., and Streets, D. G.: Characterization and source apportionment of particulate matter $\leq 2.5 \mu \mathrm{m}$ in Sumatra, Indonesia, during a recent peat fire episode, Environ. Sci. Technol., 41, 3488-3494, 2007.

Simoneit, B. R. T., Schauer, J. J., Nolte, C. G., Oros, D. R., Elias, V. O., Fraser, M. P., Rogge, W. F., and Cass, G. R.: Levoglucosan, a tracer for cellulose in biomass burning and atmospheric particles, Atmos. Environ., 33, 173-182, 1999.

Simoneit, B. R. T., Kobayashi, M., Mochida, M., Kawamura, K., and Huebert, B. J.: Aerosol particles collected on aircraft flights over the northwestern Pacific region during the ACE-Asia campaign: Composition and major sources of the organic compounds, J. Geophys. Res., 109, D19S09, doi:10.1029/2004JD004565, 2004.

SPECIATE: VOC/PM speciation Database Management system Version 4.3; U.S. Environmental Protection Agency: Research Triangle Park, available at: http://www.epa.gov/ttnchie1/ software/speciate/ (last access: 16 September 2013), NC, 2011.

Stohl, A.: Computation, accuracy and applications of trajectories A review and bibliography, Atmos. Environ., 32, 947-966, 1998.

Stohl, A. and Seibert, P.: Accuracy of trajectories as determined from the conservation of meteorological tracers, Q. J. Roy. Meteor. Soc., 124, 1465-1484, 1998.

Sundarambal, P., Balasubramanian, R., Tkalich, P., and He, J.: Impact of biomass burning on ocean water quality in Southeast Asia through atmospheric deposition: field observations, Atmos. Chem. Phys., 10, 11323-11336, doi:10.5194/acp-1011323-2010, 2010.

Turpin, B. J. and Lim, H.-J.: Species contributions to $\mathrm{PM}_{2.5}$ mass concentrations: Revisiting common assumptions for estimating organic mass, Aerosol. Sci. Tech., 35, 602-610, 2001.

US EPA, EPA-CMB8.2 Users Manual, EPA-452/R-04-011, Office of Air Quality Planning \& Standards, Research Triangle Park, NC, 2004.

Vega, E., Mugica, V., Carmona, R., and Valencia, E.: Hydrocarbon source apportionment in Mexico City using the chemical mass balance receptor model, Atmos. Environ., 34, 4121-4129, 2000.

Vega, E., Reyes, E., Ruiz, H., Garcia, J., Sanchez, G., MartinezVilla, G., Gonzalez, U., Chow, J. C., and Watson, J. G.: Analysis of $\mathrm{PM}_{2.5}$ and $\mathrm{PM}_{10}$ in the atmosphere of Mexico City during 2000-2002, J. Air. Waste. Manage., 54, 786-798, 2004.

Watson, J. G., Zhu, T., Chow, J. C., Engelbrecht, J., Fujita, E. M., and Wilson, W. E.: Receptor modeling application framework for particle source apportionment, Chemosphere, 50, 1565-1618, 2002.

White, W. H. and Roberts, P. T.: On the nature and origins of visibility-reducing aerosols in the los angeles air basin, Atmos. Environ., 11, 803-812, 1977. 
Yunker, M. B., Macdonald, R. W., Vingarzan, R., Mitchell, R. H., Goyette, D., and Sylvestre, S.: PAHs in the Fraser River basin: a critical appraisal of PAH ratios as indicators of PAH source and composition, Org. Geochem., 33, 489-515, 2002.

Zhang, T., Engling, G., Chan, C. Y., Zhang, Y. N., Zhang, Z. S., Lin, M., Sang, X. F., Li, Y. D., and Li, Y. S.: Contribution of Fungal Spores to Particulate Matter in a Tropical Rainforest, Environ. Res. Lett., 5, 024010, doi:10.1088/1748-9326/5/2/024010, 2010.
Zhang, Z. S., Engling, G., Lin, C. Y., Chou, C. C. K., Lung, S. C. C., Chang, S. Y., Fan, S. J., Chan, C. Y., and Zhang, Y. H.: Chemical speciation, transport and contribution of biomass burning smoke to ambient aerosol in Guangzhou, a mega city of China, Atmos. Environ., 44, 3187-3195, 2010. 